\title{
Nutrient and plankton dynamics during a spring drift experiment in the German Bight
}

\author{
Thomas U. Raabe ${ }^{1, *}$, Uwe H. Brockmann ${ }^{1}$, Claus-Dieter Dürselen ${ }^{2}$, Michael Krause ${ }^{3}$, \\ Hans-Josef Rick ${ }^{4}$ \\ 'Zentrum für Meeres- und Klimaforschung der Universität Hamburg, Institut für Biogeo- und Meereschemie, \\ Martin-Luther-King-Platz 6, D-20146 Hamburg, Germany \\ ${ }^{2}$ Institut für Chemie und Biologie des Meeres, Carl-von-Ossietzky-Universität, Postfach 2503, D-26111 Oldenburg, Germany \\ ${ }^{3}$ Institut für Allgemeine Botanik, Universität Hamburg, Ohnhorststr 18, D-22607 Hamburg, Germany \\ ${ }^{4}$ Institut für Meereskunde an der Universität Kiel, Düsternbrookerweg 20, D-24105 Kiel, Germany
}

\begin{abstract}
The German Bight contains waters of mixed origin: freshwater input from the rivers Elbe, Ems and Weser, Wadden Sea water that is rich in organic compounds, and highly saline water ( $>33 \mathrm{SU}$ ) from the central North Sea. In order to investigate the very complex biological and biogeochemical situation caused by the various types of fronts and different water bodies, a spring drift experiment was carried out in this area following a survey of 45 stations covering the German Bight. A typical springtime situation was found: diatom blooms (biomasses $>500 \mu \mathrm{g} \mathrm{Cl}^{-1}$ in the mouth of the river Elbe) had decreased the silicate to around $0.3 \mu \mathrm{M}$; phosphate concentrations $(<0.03 \mu \mathrm{M})$ were limiting primary production in the northeastern part of the investigated area, but, due to remineralization processes and riverine entrainment, they showed higher values in the south and in the river Elbe mouth $(>0.3 \mu \mathrm{M})$. Nitrate ranged from 10 to $40 \mu \mathrm{M}$ and was clearly dominated by the river Elbe input. From the southwest a beginning bloom of Phaeocystis globosa spread into the drift area and, later on, into the whole German Bight. Zooplankton biomass was highest along the North Frisian coast $\left(>50 \mu \mathrm{g} \mathrm{Cl}^{-1}\right.$ ), and was dominated by copepods at the northwestern border of the German Bight and in the drift area. During the drift experiment, 2 phases and a transition state could be distinguished: $n$ ne first phase, the total phytoplankton biomass was low and nutrient concentrations remained relatively constant. In the transition state, strong wind forces moved the drifter southwards into another water body. A significant drop in nitrate, nitrite and phosphate concentrations was observed, whereas silicate concentrations almost doubled. During the second phase of the experiment, a strong increase of total phytoplankton biomass (cell size $>5 \mu \mathrm{m}$ ) was recorded, dominated by P. globosa ( $>95 \%$ ) and accompanied by rising concentrations of particulate compounds. Simultaneously, the nutrient concentrations declined, and the zooplankton biomass reached minimum values. At a depth of $10 \mathrm{~m}$, ammonium and phosphate concentrations showed strong diurnal variations, indicating enhanced planktonic activity during the third phase. Summing up the results, the overall evaluation of the drift experiment as a method for studying in situ biological and biogeochemical processes within the same water body was positive
\end{abstract}

KEY WORDS: German Bight $\cdot$ Phytoplankton $\cdot$ Zooplankton $\cdot$ Nutrients $\cdot$ Drift experiment

\section{INTRODUCTION}

The German Bight is a shallow region of the North Sea with depths mainly between 20 and $40 \mathrm{~m}$. Freshwater input from the rivers Elbe, Ems and Weser fluctuates, so that in this area 3 different types of fronts can be classified (Krause et al. 1986, Budéus 1989, Dippner

•E-mail: traabe@uni-hamburg.de
1993). As a result of different physical, biogeochemical and biological conditions on both sides of the fronts and such factors as the accumulation of substances contained in river outflow, the mixing areas become very heterogeneous and form complex systems. Various biological and biogeochemical processes are found, particularly in the boundary layers of these fronts (Brockmann et al. 1990, Mills \& Tett 1991, Munk 1993). Apart from the fronts causing enhanced bioac- 
tivity, the phase-transfer processes within a given water body are also very important: the transformation processes between dissolved nutrients and particulate (organic) matter, e.g phyto-and zooplankton, control the production and degradation of biomass. Phasetransfer processes also play a leading role in the transport of contaminants, since the distribution of compounds such as heavy metals or PCBs is closely related to the transport and distribution of particulate matter (Pohlmann \& Puls 1994).

In order to investigate the distribution and variability of physical, biogeochemical and biological parameters in the German Bight, several large-scale experiments and cruises have been conducted during the last $10 \mathrm{yr}$ : the Sonderforschungsbereich 94 (1972-1985, Hamburg, 'Marine Research'; Sündermann \& Lenz 1983), the projects ZISCH (1984-1989, 'Circulation and contaminant fluxes in the North Sea'; Sündermann 1994) and TUVAS (1990-1992, 'Transport, turnover and variability of pollutants in the German Bight', Bundesamt für Seeschiffahrt und Hydrographie; BSH 1993) as well as the longterm monitoring programs at Helgoland (1962-1991. Biologische Anstalt Helgoland; BAH 1992).

The main objectives of the project PRISMA (1990 to 1993) were to investigate the transport and transformation processes of chemical and biogeochemical compounds in the German Bight. To achieve these goals, 4 surveys (with RV 'Gauss') and 3 drift experiments (with RV 'Valdivia') were carried out in April 1991. Basic hydrographic, meteorological, chemical, biochemical and biological parameters were recorded on a large scale (10 to $20 \mathrm{~km}$ on the surveys) and on a finer scale ( 3 to $5 \mathrm{~km}$ around the drifter). The complete water column was sampled to obtain a data set with the best possible resolution in time and space (Brockmann et al. 1997 in this volume). Some results of the analyses of nutrients at $10 \mathrm{~m}$ depth as well as of phytoplankton and zooplankton integrated over all depths, collected during a survey and a subsequent drift experiment, are presented here.

\section{MATERIAL AND METHODS}

Between April 17 and 20, 1991, a survey of the German Bight was performed which included a grid of 45 stations. Furthermore, 3 drift experiments were carried out with the RV 'Valdivia' The last of these experiments was conducted from April $22(18: 00 \mathrm{~h})$ to April $29,1991(12: 00 \mathrm{~h})$ about $70 \mathrm{~km}$ northwest of Helgoland. For a detailed description of the measurement strategy see Brockmann et al. (1977).

Sampling and analysis of nutrients. Nutrient analyses were carried out on water samples filtered over precombusted glass fiber filters (Whatman GF/C) at low pressure ( $\leq 0.2$ bar below normal pressure). Concentrations of nitrate, nitrite, phosphate, silicate and ammonium were measured with a Technicon AutoAnalyzer System II (Grasshoff 1983). Total dissolved nitrogen and phosphorus were analysed with an AutoAnalyzer following wet-chemical oxidation with peroxodisulphate in an autoclave. Dissolved organic nitrogen and phosphorus concentrations were calculated from the differences between total dissolved nitrogen and inorganic nitrogen and total dissolved phosphorus and phosphate, respectively. In addition to dry weight, particulate phosphorus and total. particulate carbohydrates were determined from filters by colorimetric analysis after oxidation with sulphuric acid/hydrogen peroxide.

Sampling and analysis of phytoplankton. Water samples from a rosette sampler were preserved with formalin solution to a final concentration of $1 \%$. The phytoplankton composition (cell size $>5 \mu \mathrm{m}$ ) was determined by inverted microscopy, using the method of Utermöhl $(1931,1958)$. To calculate the biomass, a geometrical body was assigned to each phytoplankton species, and the necessary parameters for determining volume and surface area were measured. Subsequently, conversion to carbon content was made according to Strickland \& Parsons (1972).

Carbon content was integrated over a water column of $1 \mathrm{~m}^{2}$, assuming a euphotic zone of maximum $30 \mathrm{~m}$ depth, and converted to 1 I to enable the comparison of biomass at different stations.

Due to limited ship time and laboratory space aboard the research vessels, no analyses of nano- and picophytoplankton were carried out during the investigations. This is a shortcoming of the study, because at times these plankton species can account for the highest fraction of the primary production. But as will be shown by some nutrient calculations below, the main part of the phytoplankton stock in April 1991 must have consisted of species $>5 \mu \mathrm{m}$. Thus, the error resulting from omitting the small phytoplankton fraction should be negligible.

Sampling and analysis of zooplankton. Zooplankton samples were collected with a WP-2 net (mesh size $200 \mathrm{jm}$ ) from near the bottom up to the surface. The material was preserved in a solution of formaldehyde in seawater $(4 \%)$ saturated with hexamethylenetetramine as a buffer.

Selected parts of the samples were sorted for taxonomic analysis. For the quantification of zooplankton biomass the numbers of meso- and macrozooplankton individuals per $\mathrm{m}^{3}$ were counted for different zooplankton taxa. The major copepods were determined to either species or group level. Nauplii stages were not measured, since they are small enough to pass through the meshes. The numbers per $\mathrm{m}^{3}$ of meso-and macrozooplankton were converted to dry weight using 
conversion factors given by Hagmeier (1961), Comita et al. (1966), Hillebrandt (1972), Kirkegaard \& Lassen (1980), Williams \& Lindley (1980), Daro \& Gijsegem (1982), Harms et al. (1994). Biomasses ( $\mu \mathrm{g}$ C) were calculated from dry weight following Cushing et al. (1958). Microzooplankton such as ciliate species and bacterioplankton were not determined.

\section{RESULTS}

During the drift experiment, moderate winds prevailed, varying between east and north, except that on April 27 maximum velocities $>15 \mathrm{~m} \mathrm{~s}^{-1}$ were recorded.

The mean water temperatures ranged from $6.3^{\circ} \mathrm{C}$ (western German Bight) to $7.5^{\circ} \mathrm{C}$ (North Frisian coast). South of Helgoland, thermohaline stratification was observed. At the beginning of the drift experiment, the drifter was located east of the upwelling region on the border of the stratified region. For more detailed information on the meteorological and hydrographic situation see Schrum et al. (1997 in this volume).

\section{Horizontal nutrient distribution}

The nutrient status as observed during the first survey of RV 'Gauss', just before the drift experiment, is given in Figs. 1 to 7 .

The gradients of nitrate, ranging from $<10 \mu \mathrm{M}$ (northwest) to $>40 \mu \mathrm{M}$ (mouth of the river Elbe), were clearly dominated by the discharge of the river Elbe (Fig. 1). The impact of river input on the nutrient status in the German Bight has been described before by Brockmann \& Eberlein (1986).

As has already been described for the salinities (Schrum et al. 1997 in this volume), the plume of the Elbe river, containing 20 to $30 \mu \mathrm{M}$ nitrate, first passed Helgoland and then turned north along the North Frisian coast. At the $10 \mathrm{~m}$ depth investigated, there was a very highly significant negative linear correlation ( $\mathrm{p}<0.001, \mathrm{r}^{2}=0.91, \mathrm{n}=43$ ) between salinity and nitrate concentration throughout the German Bight. Based on this linear regression, a 'dilution factor' of $0.5 \mu \mathrm{mol} \mathrm{NO}_{3} \mathrm{~km}^{-1}$ in a northwesterly direction was calculated, defining the German Bight as a mixing area of nitrate-rich Elbe water with North Sea water containing less nutrients.

The isopleths of the horizontal distribution of phosphate (Fig. 2) expressed no significant front: maximum concentrations of $>0.4 \mu \mathrm{M}$ were found close to the mouth of the Elbe, and minima of $<0.03 \mu \mathrm{M}$ (limiting primary production) were measured in the northeast near the island of Sylt. At the other stations, concentrations ranged from 0.1 to $0.3 \mu \mathrm{M}$.

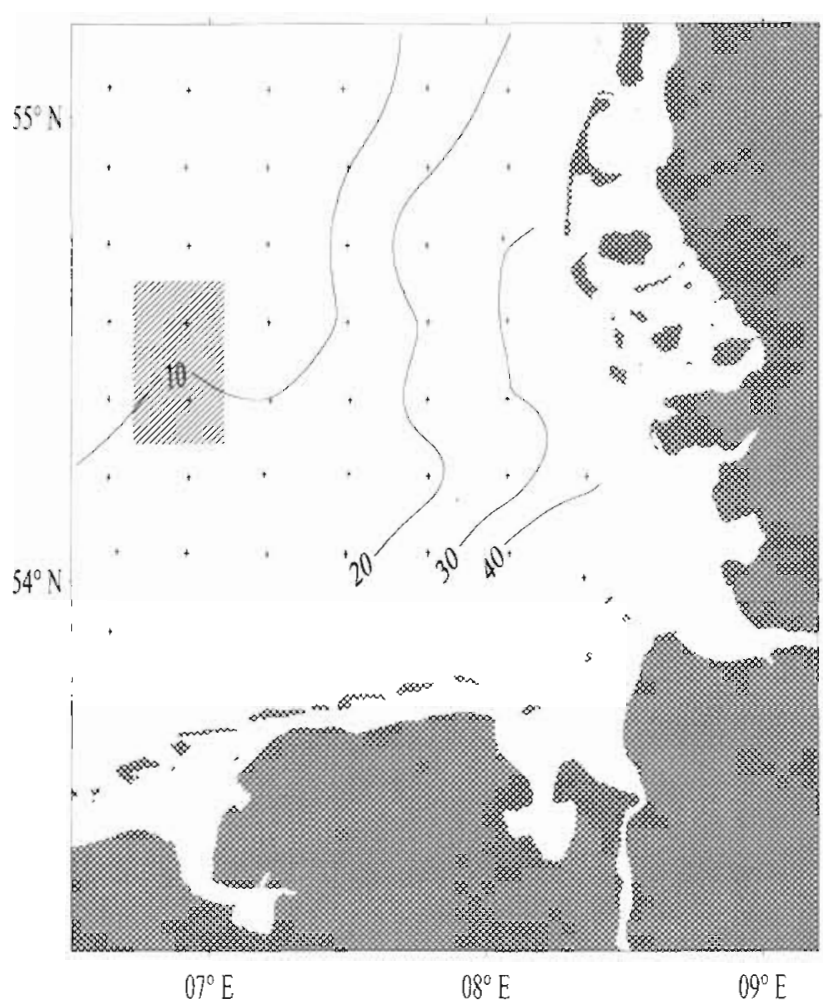

Fig. 1. Nitrate concentrations $(\mu \mathrm{M})$ in the German Bight from April 12 to 20, 1991, at $10 \mathrm{~m}$ depth (hatched rectangle: drift area)

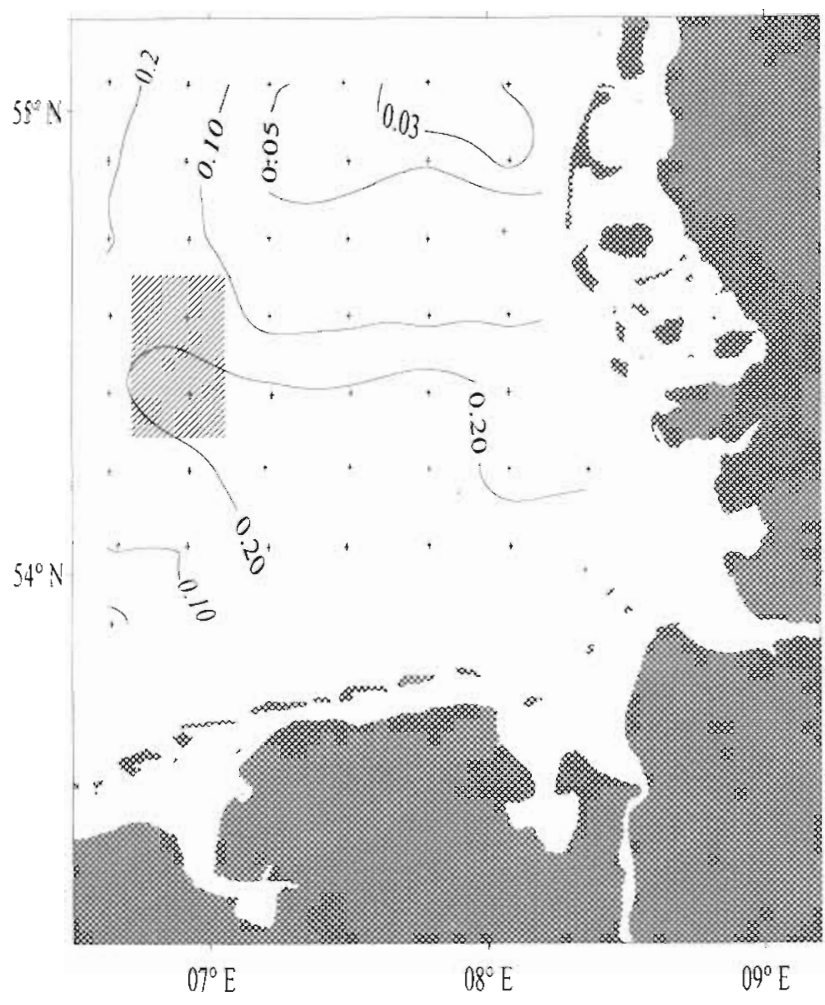

Fig. 2. Phosphate concentrations $(\mu \mathrm{M})$ from April 12 to 20,1991 , at $10 \mathrm{~m}$ depth 
During the investigation, silicate concentrations were low, around $0.3 \mu \mathrm{M}$. Only in the far north and southwest of the investigated area were higher concentrations of $>0.7$ and $1.3 \mu \mathrm{M}$, respectively, observed (Fig. 3). The area of the drift experiment was located in the southwest gradient where concentrations of silicate rose from 0.3 to $0.7 \mu \mathrm{M}$.

Fig. 4 shows the summed concentrations of ammonium and nitrite, which are indicators of degradation of organic material by either zooplankton grazing or microbial activities of bacteria (Brockmann et al. 1994) and subsequent nitrification.

Mean summed concentrations of ammonium and nitrite were $1.7 \mu \mathrm{M}$, and maximum values of more than 2.1 $\mu \mathrm{M}$ were found in the western part of the German Bight (drift area) as well as in the mouth of the Elbe river. They were accompanied by relatively low values of dissolved oxygen (below $330 \mu \mathrm{M}$ ), due to oxidation and nitrification processes (Fig. 5).

There was a highly significant, negative linear correlation between ammonium plus nitrite concentrations and oxygen content $\left(\mathrm{p}<0.01, \mathrm{r}^{2}=0.348, \mathrm{n}=44\right)$ at $10 \mathrm{~m}$ depth. No strong vertical gradients were found for the concentrations of ammonium plus nitrite and oxygen. Concentrations of particulate phosphorus and particulate carbohydrates formed an east-west gradient. More than $0.5 \mu \mathrm{M}$ of particulate phosphorus (Fig. 6) and

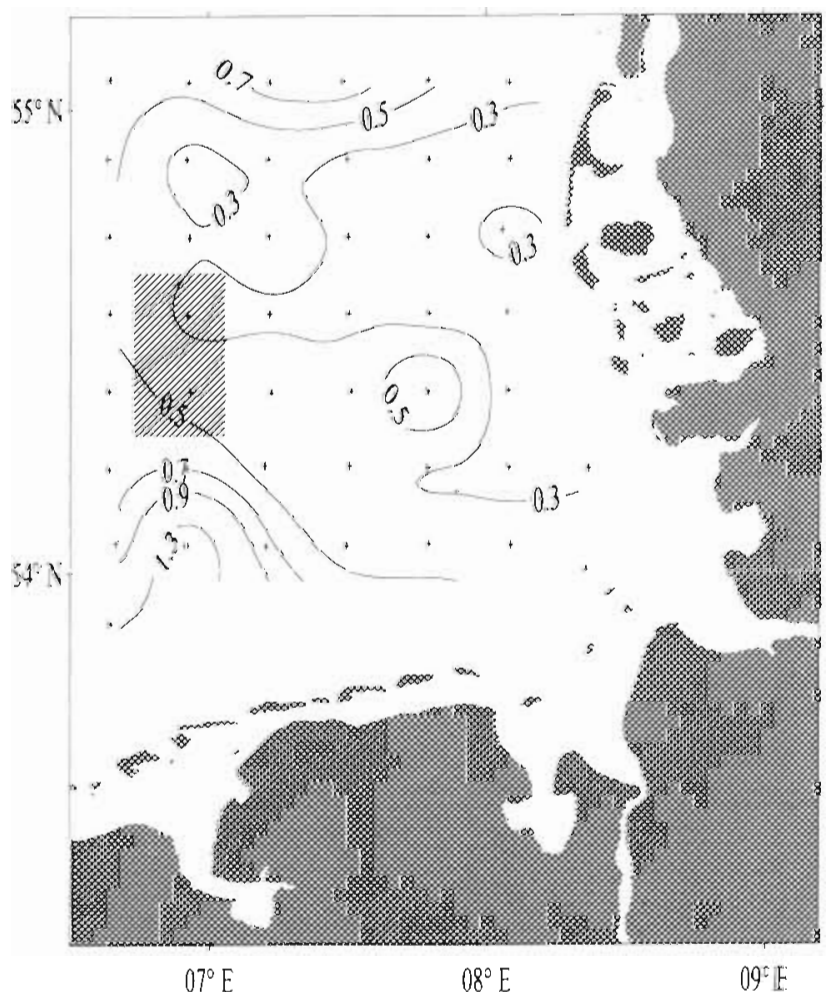

Fig. 3. Silicate concentrations ( $\mu$ M) from April 12 to 20, 1991, at $10 \mathrm{~m}$ depth

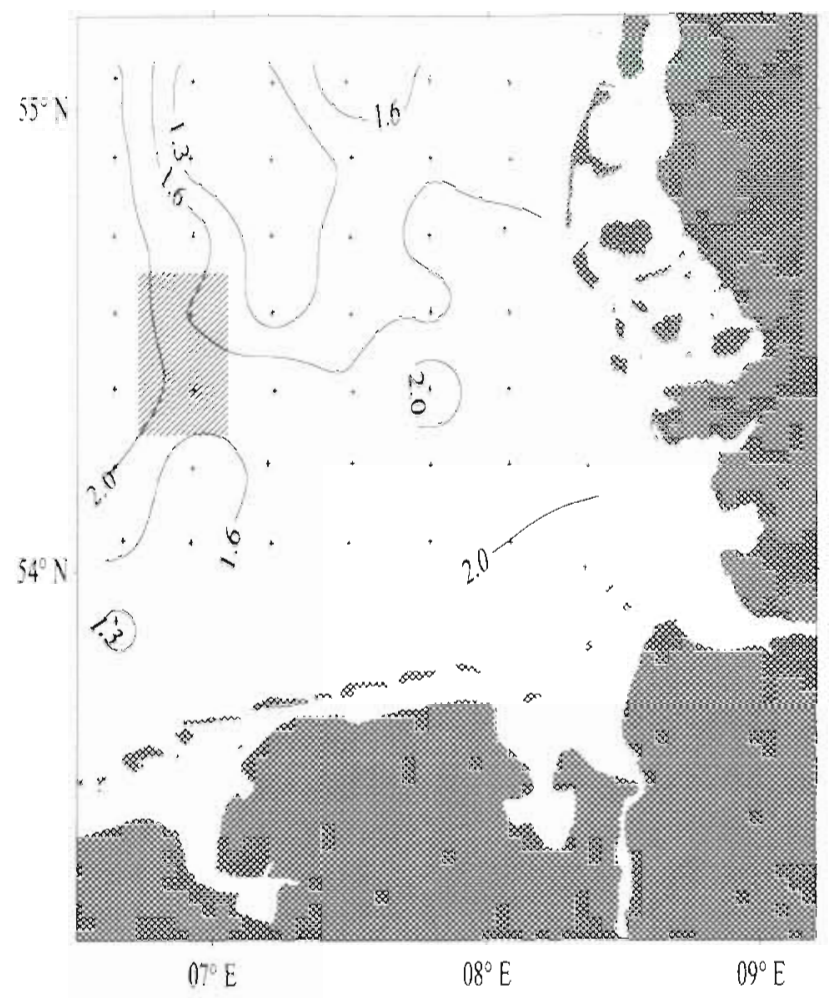

Fig. 4. Ammonium + nitrite concentrations $(\mu \mathrm{M})$ from April 12 to 20,1991 , at $10 \mathrm{~m}$ depth

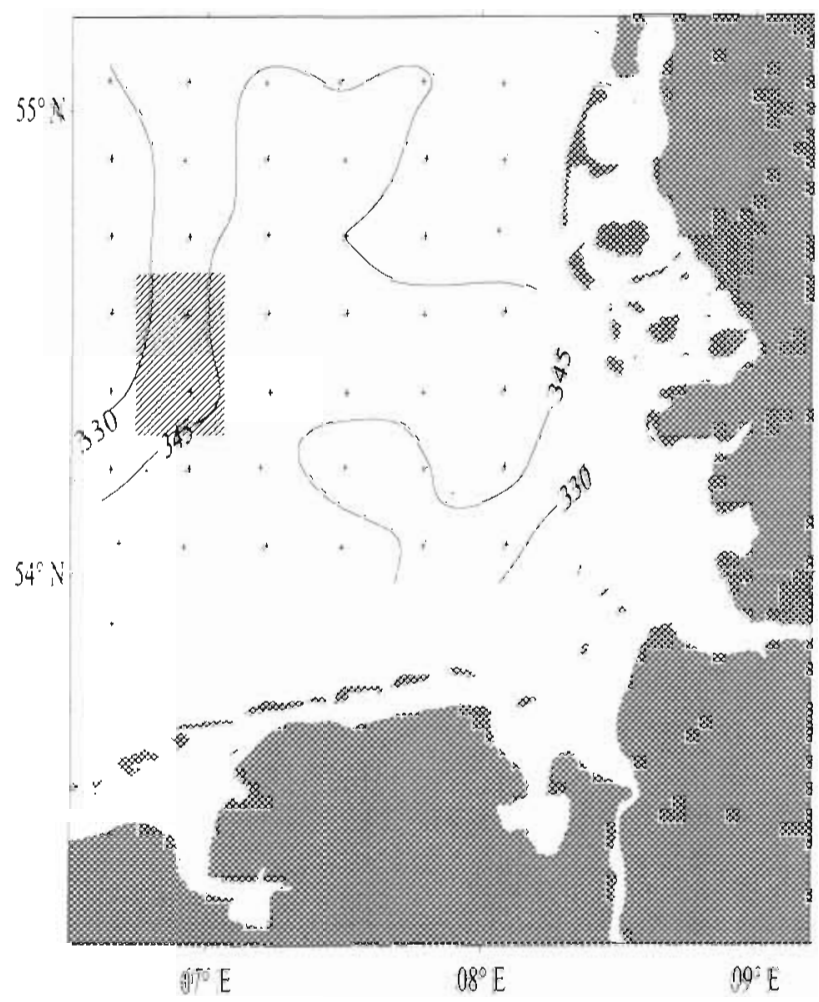

Fig. 5. Oxygen concentrations ( $\mu$ M) from April 12 to 20, 1991, at $10 \mathrm{~m}$ depth 


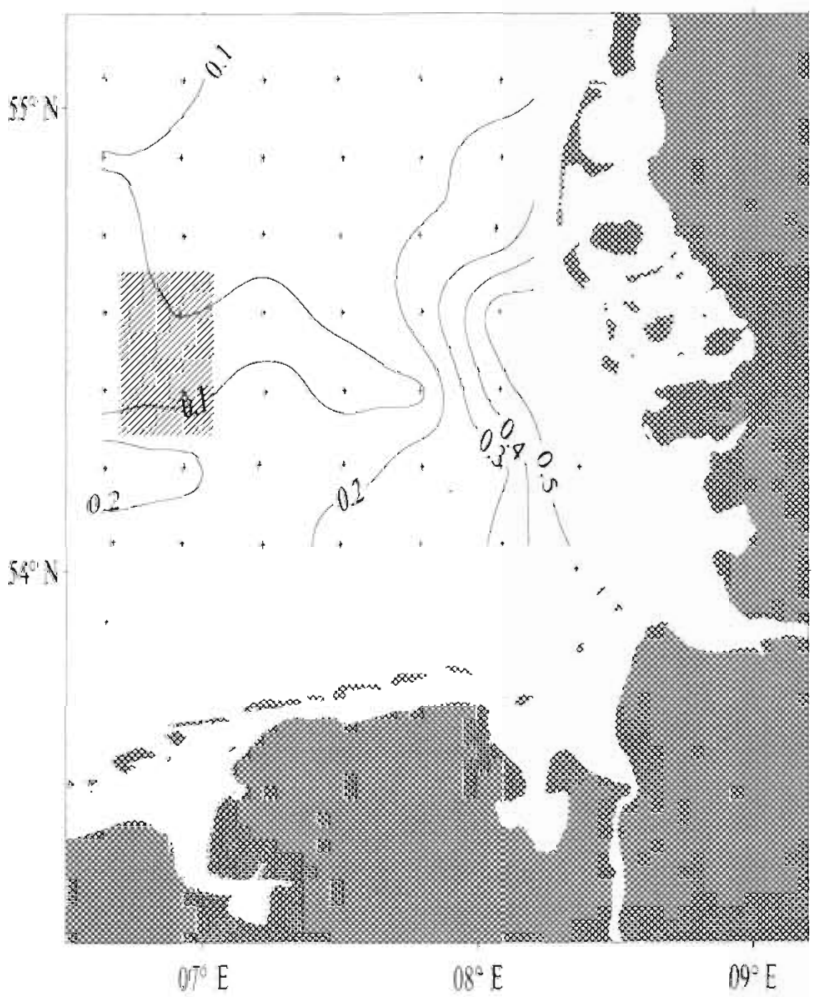

Fig. 6. Concentrations of total particulate phosphorus ( $\mu \mathrm{M})$ from April 12 to 20,1991 , at $10 \mathrm{~m}$ depth

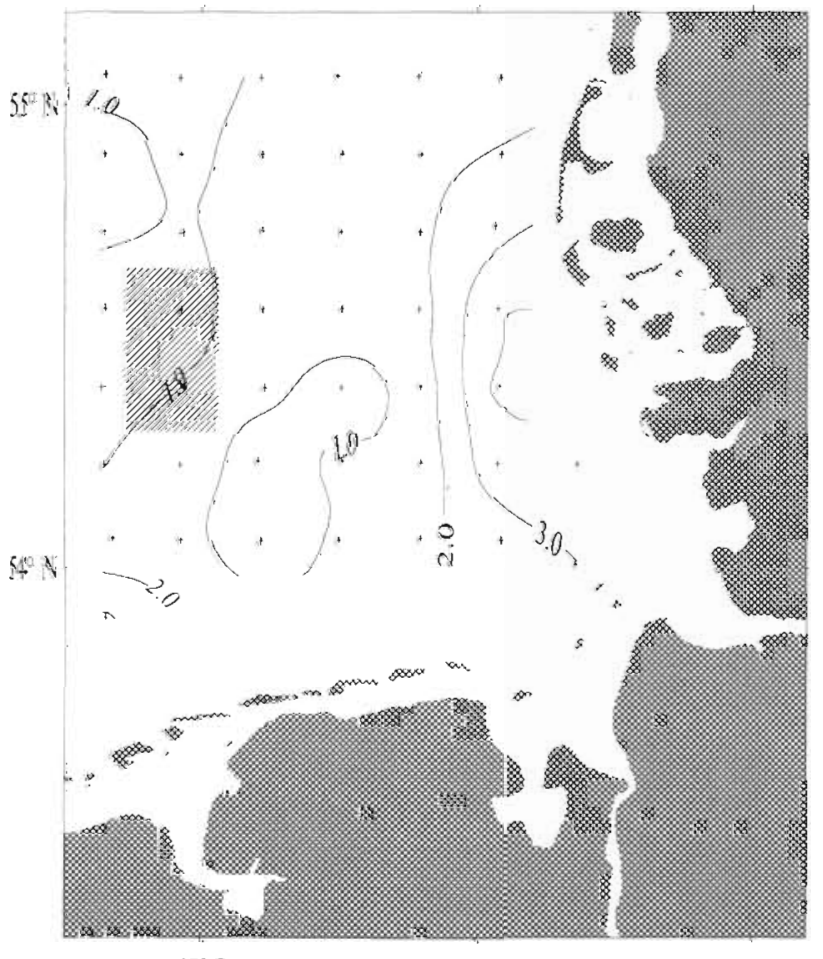

$07^{\circ} \mathrm{E}$

$08^{\circ} \mathrm{E}$

$09^{\circ} \mathrm{E}$

Fig. 7 Concentrations of total particulate carbohydrates ( $\mu \mathrm{M}$ Glc eq) from April 12 to 20,1991, at $10 \mathrm{~m}$ depth more than $3 \mu \mathrm{M}$ Glc eq (glucose equivalents) of total particulate carbohydrates (Fig. 7) were measured off the North Frisian coast, mainly at the western boundary of the Wadden Sea.

In the drift area, concentrations were generally lower. Slightly higher amounts of particulate phosphorus $(0.2 \mu \mathrm{M})$ and carbohydrates (1 $\mu \mathrm{M}$ Glc eq) were found in the southern part than in the northern part $(0.06 \mu \mathrm{M}$ and $0.6 \mu \mathrm{M}$ Glc eq, respectively).

\section{Phytoplankton biomass}

The highest phytoplankton density (cell size $>5 \mu \mathrm{m}$ ) was found in the southeastern part of the German Bight, off the mouth of the river Elbe, with concentrations $>400 \mu \mathrm{g} \mathrm{C} \mathrm{l}^{-1}$, at times exceeding $600 \mu \mathrm{g} \mathrm{C} \mathrm{^{-1 }}$ (Fig. 8). Along the North Frisian coast, concentrations between 50 and $300 \mu \mathrm{g} \mathrm{Cl}^{-1}$ were measured. This was in contrast to the western German Bight where phytoplankton biomass was $<5 \mu \mathrm{g} \mathrm{Cl}^{-1}$

The phytoplankton communities in the eastern part of the area were dominated by diatoms (Fig. 9), and around Helgoland Thalassiosira nordenskiöldii reached a maximum biomass of $400 \mu \mathrm{g} \mathrm{C} \mathrm{l}^{-1}$. During further surveys up to the end of April, at the same time as the drift experiment, it was noted that the numbers

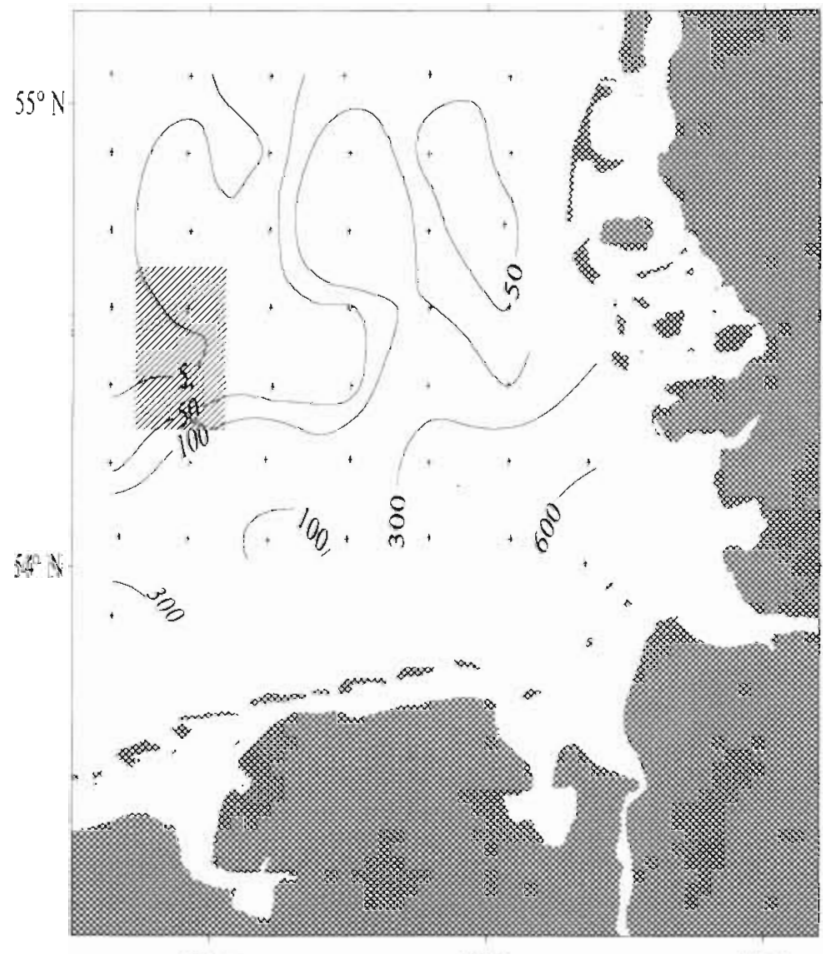

$07^{\circ} \mathrm{E}$

$08^{\circ} \mathrm{E}$

$09^{\circ} \mathrm{E}$

Fig. 8. Total depth-integrated phytoplankton biomass ( $\mu \mathrm{g} \mathrm{C}$ $1^{-1}$, cell size $>5 \mu \mathrm{m}$ ) from April 12 to 20,1991 


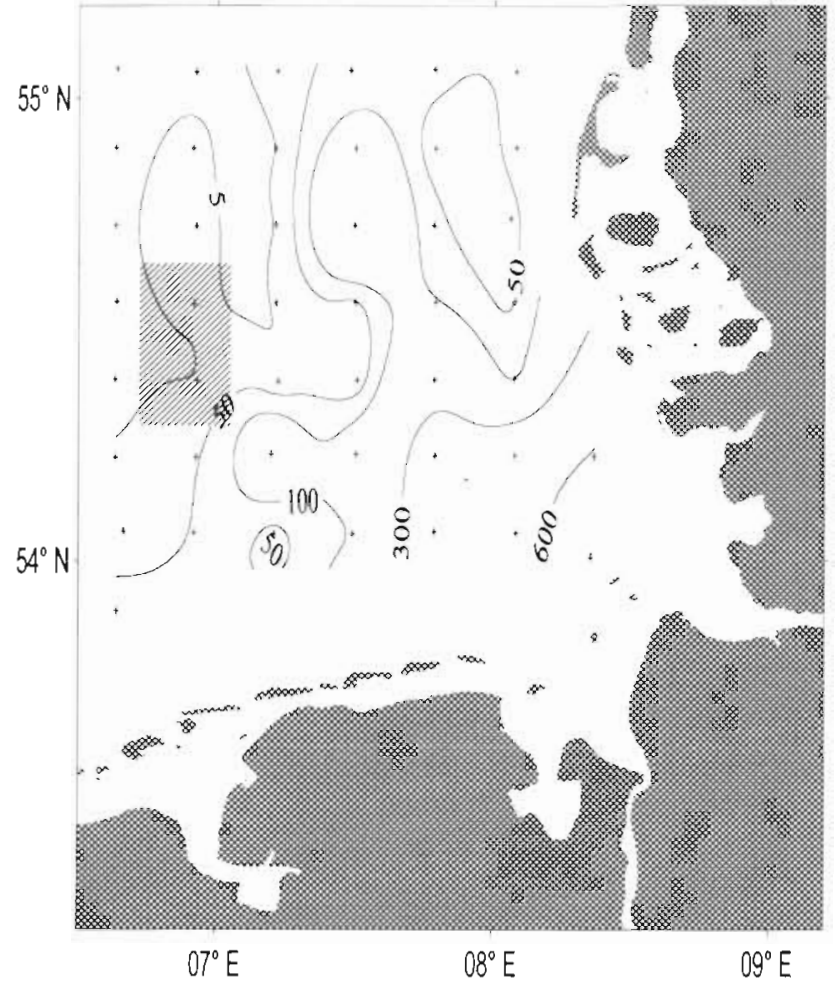

Fig. 9. Depth-integrated diatom biomass $\left(\mu \mathrm{g} \mathrm{C} \mathrm{l}^{-1}\right.$, cell size $>5 \mu \mathrm{m}$ ) from April 12 to 20,1991

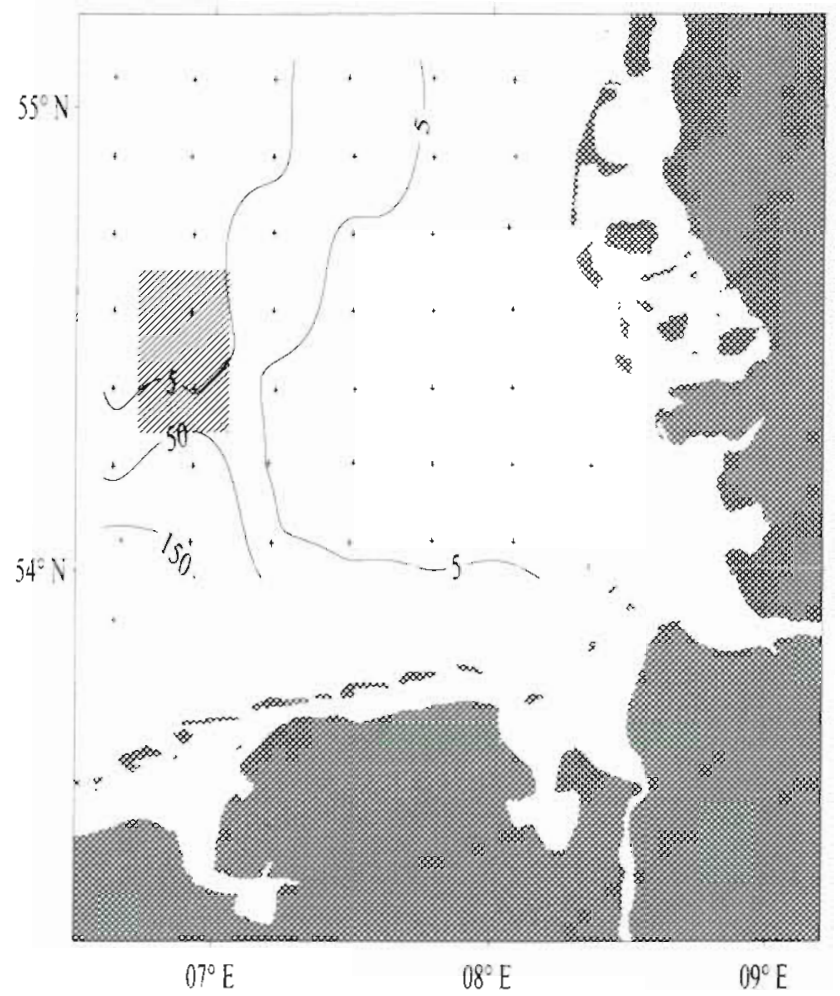

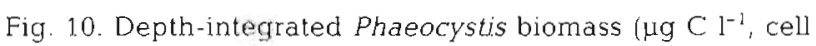
size $>5 \mu \mathrm{m}$ ) from April 12 to 20,1991

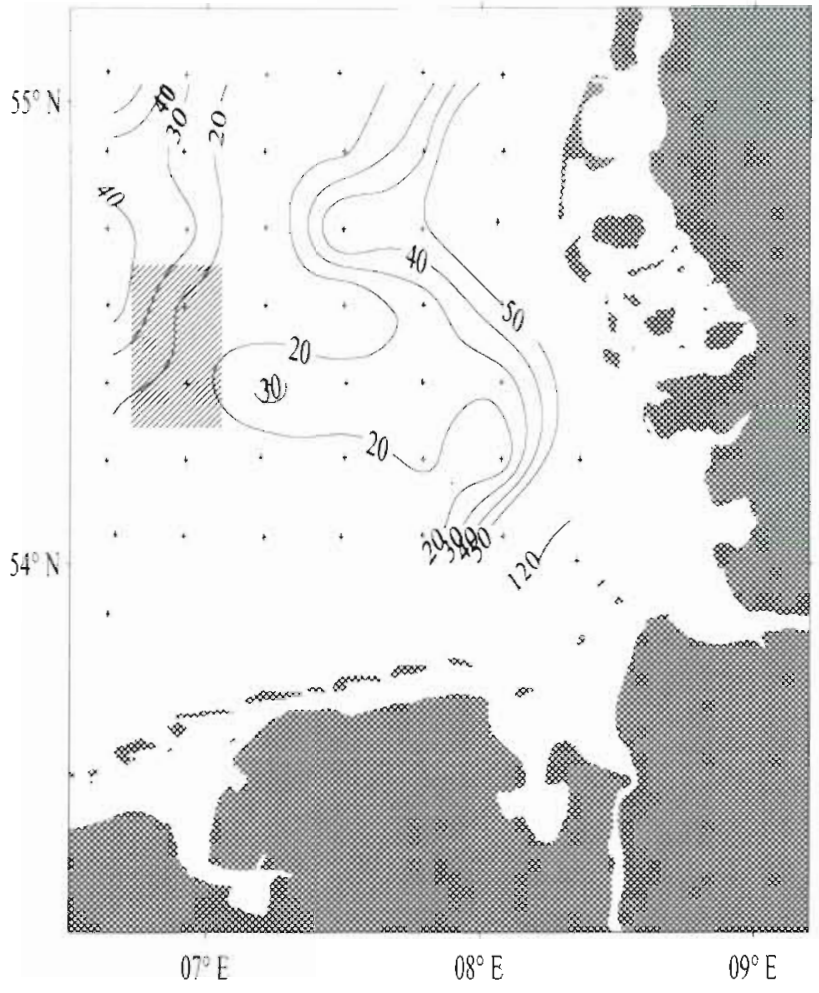

Fig. 11 Total depth-integrated zooplankton biomass $\left(\mu \mathrm{C} \mathrm{Cl}^{-1}\right)$ from April 12 to 20, 1991

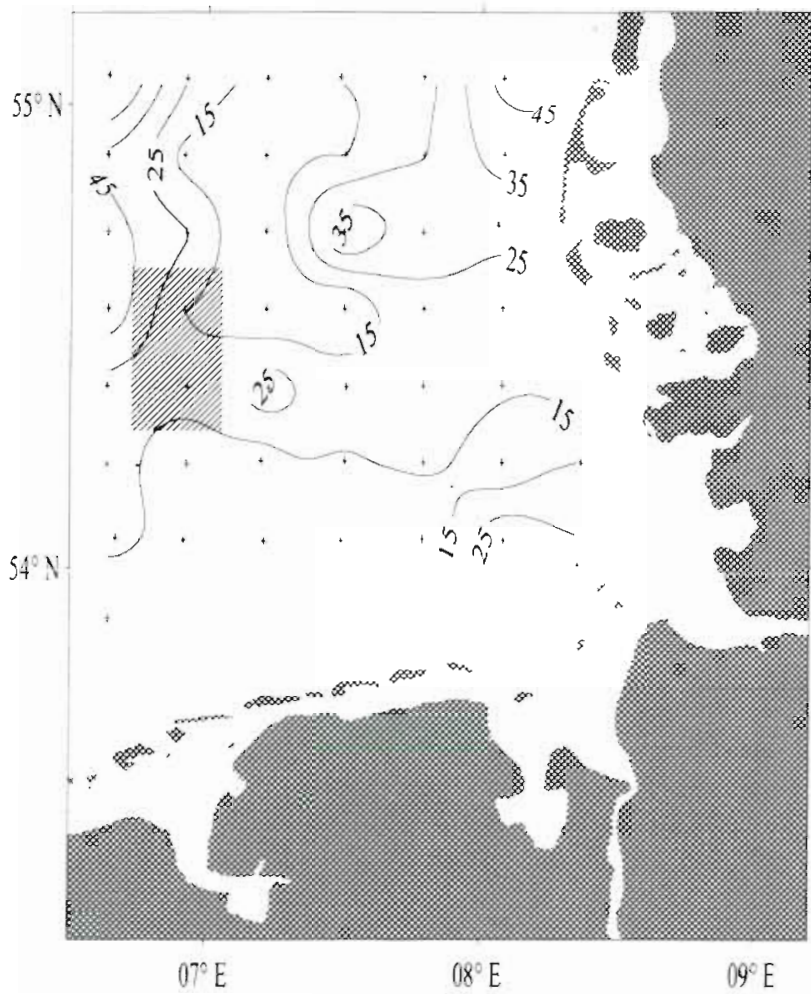

Fig. 12. Depth-integrated copepod biomass $\left(\mu g \mathrm{C}^{-1}\right)$ from A pril 12 to 20, 1991 
of T. nordenskiöldii decreased and were succeeded by increasing numbers of Ditylum brightwellii. This species had previously been found only in the southeast and northeast. Other important diatoms were Thalassiosira rotula found in the east, Thalassiosira punctigera and various Rhizosolenia species in the south, Odontella aurita, some Chaetoceros species, Skeletonema costatum and Cerataulina pelagica in the southeast and Thalassiosira fallax and Asterionella glacialis in the northeast. Coscinodiscus wailesii was observed in the middle and northeast of the German Bight.

In the southwest and in northern parts of the German Bight the prymnesiophycean Phaeocystis globosa dominated the phytoplankton communities (Fig. 10),

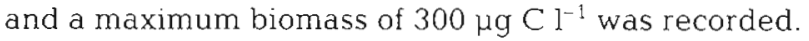
A final sampling of the grid at the end of April showed this species had spread towards the northeast of the German Bight. This algal succession with diatoms followed by flagellates is a classical phenomenon in continental coastal water (Lancelot 1990).

At the beginning of the drift experiment (April 23), the southern part of the drift area was a mixing zone of decreasing diatom numbers (still up to $20 \mu \mathrm{g} \mathrm{Cl}^{-1}$ ) and increasing Phaeocystis globosa (about $20 \mu \mathrm{g} \mathrm{C} \mathrm{l}^{-1}$ ).

\section{Horizontal zooplankton abundance}

During the mid-April survey, areas of high total zooplankton biomass (species $>200 \mu \mathrm{m}$ ) were found at the northwestern boundary $\left(>40 \mu \mathrm{g} \mathrm{C} \mathrm{l}^{-1}\right)$, in the mouth of

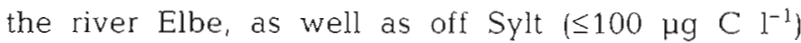
(Fig. 11). The mesozooplankton was dominated by copepods, mainly small species such as Pseudocalanus elongatus, Temora longicornis, Centrophages hamatus and Acartia clausi. Higher concentrations of more than $25 \mu \mathrm{g} \mathrm{C} \mathrm{C}^{-1}$ were found off the island Sylt, in the far northwest and in the mouth of the river Elbe (Fig. 12). The coastal maxima were mainly represented by bottom invertebrate larvae and hydromedusae.

Offshore in the German Bight, i.e. the western part of the investigated area, species of the open North Sea such as the large calanoid copepod Calanus spp. as well as the small cyclopoid Oithona spp. occurred.

\section{Nutrients during the drift experiment}

During the first 3 days of the drift experiment, the concentrations of all nutrients at $10 \mathrm{~m}$ depth remained relatively constant at Stn $\mathrm{Z}$ (the central drifting station): nitrate ranged from 6.7 to $7.5 \mu \mathrm{M}$ (Fig. 13), silicate from 4.5 to $5.5 \mu \mathrm{M}$ (Fig. 14) and nitrite from 0.31 to $0.26 \mu \mathrm{M}$ (Fig. 15).

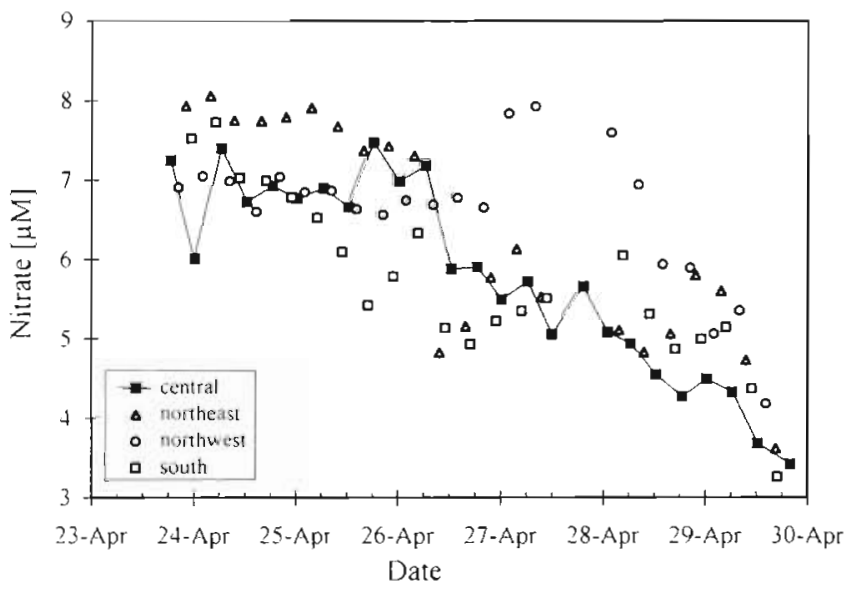

Fig. 13. Nitrate concentrations during the drift experiment in 1991 at $10 \mathrm{~m}$ depth at the central station (drift buoy) and surrounding NE, NW and S stations

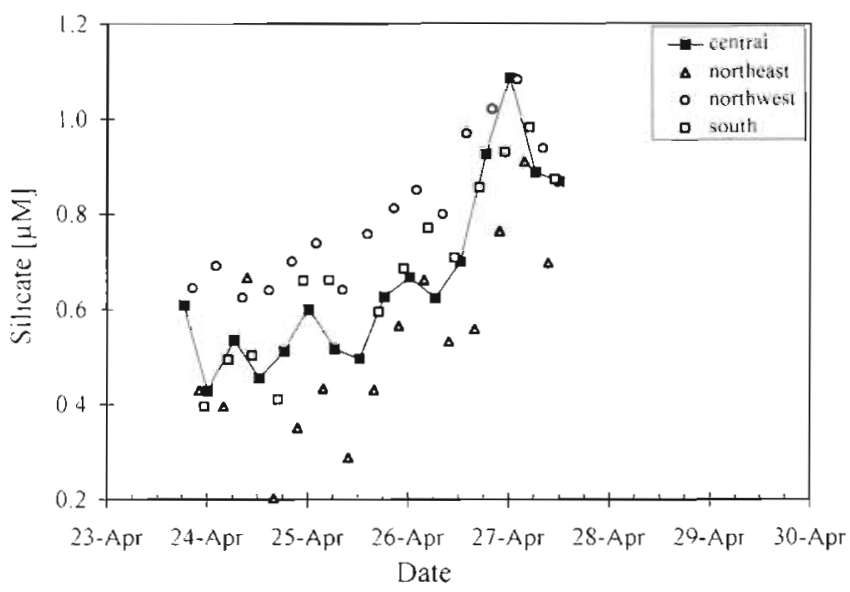

Fig. 14. Silicate concentrations during the drift experiment in 1991 at $10 \mathrm{~m}$ depth at the 4 stations

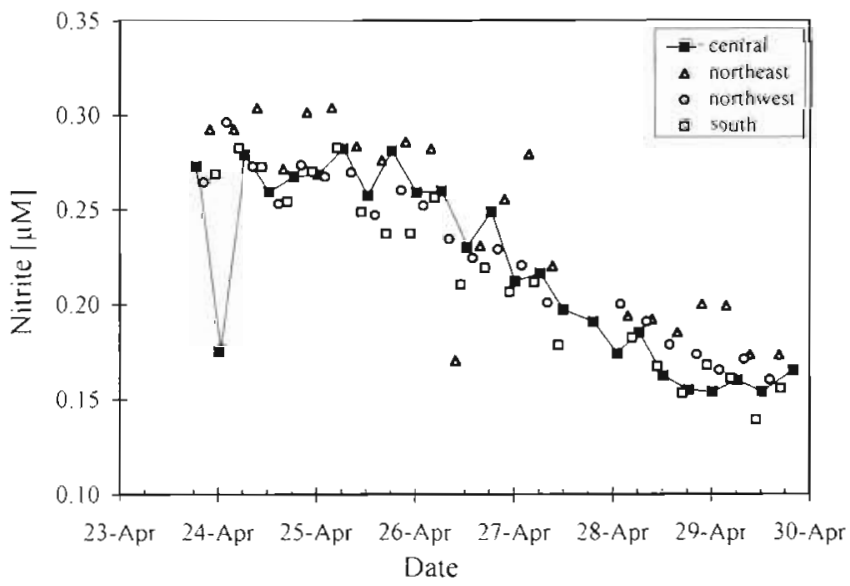

Fig. 15. Nitrite concentrations during the drift experiment in 1991 at $10 \mathrm{~m}$ depth at the 4 stations 
At the same time, phosphate concentrations decreased slightly from 0.14 to $0.10 \mu \mathrm{M}$ (Fig 16). Ammonium concentrations had a mean value of $1.13 \mu \mathrm{M}$ with a high standard deviation of $0.56 \mu \mathrm{M}$ (Fig. 17).

Total particulate carbohydrates ranged from 0.7 to $1.5 \mu \mathrm{M}$ Glc eq, particulate phosphorus from 0.10 to $0.20 \mu \mathrm{M}$ (Figs. $18 \& 19$ ). The minima and maxima of the total particulate carbohydrates corresponded well with maxima and minima of ammonium.

At the northeast (NE) drifter station, slightly higher concentrations of nitrate $(+0.7$ to $+1 \mu \mathrm{M})$, nitrite $(+0.03 \mu \mathrm{M})$ and phosphate $(+0.03 \mu \mathrm{M})$ were measured during the first $3 \mathrm{~d}$ of the experiment, indicating the entrainment of nutrient enriched water. This is supported by the lower temperatures and higher salinity values reported by König \& Schrum (1997 in this volume), and was probably due to the station's proximity to the upwelling region west of Helgoland.

On April 24 (midnight), all nutrients showed a sharp decrease in concentration at $10 \mathrm{~m}$ depth at Stn Z. At the same time the temperature rose by more than $0.1^{\circ} \mathrm{C}$ and phytoplankton and zooplankton biomasses showed relative maxima (see below). This effect was not observed at other depths at this station nor at Stns NE, NW or S surrounding the central station. By the next sampling at Stn Z (at 06:25 h) all nutrients had returned to the starting concentrations.

Just after an increase of nitrate $(+0.7 \mu \mathrm{M})$, phosphate $(+0.15 \mu \mathrm{M})$ and silicate $(+0.15 \mu \mathrm{M})$ during the daytime on April 25, all nutrients showed a significant shift in concentrations until the beginning of April 27: nitrate, phosphate and nitrite concentrations decreased, while silicate and total particulate carbohydrates increased. At the same time, the particulate phosphorus concentrations doubled from 0.16 to $0.33 \mu \mathrm{M}$.

From April 27 until the end of the drift experiment on April 29, concentrations of nitrate and nitrite steadily declined to below 3.5 and $0.17 \mu \mathrm{M}$, respectively. Phosphate and ammonium slightly decreased, too, but showed large diurnal variations. The total particulate carbohydrate concentration doubled from 0.15 to $0.3 \mu \mathrm{M}$ Glc eq, while particulate phosphorus showed a slighter increase from 0.33 to $0.4 \mu \mathrm{M}$. Here again major daily variations were observed.

Contents of total dissolved organic nitrogen (DON, Fig 20) had a mean value of $8.2 \mu \mathrm{M}$ before April 27 , with peak maxima of about $12 \mu \mathrm{M}$ during midnight on April 24 and 25. After April 27 the mean concentration rose to $11.1 \mu \mathrm{M}$, maxima being more than $15 \mu \mathrm{M}$.

\section{Phytoplankton during the drift experiment}

During the whole drift experiment, Phaeocystis globosa was the dominant species in the area, forming at

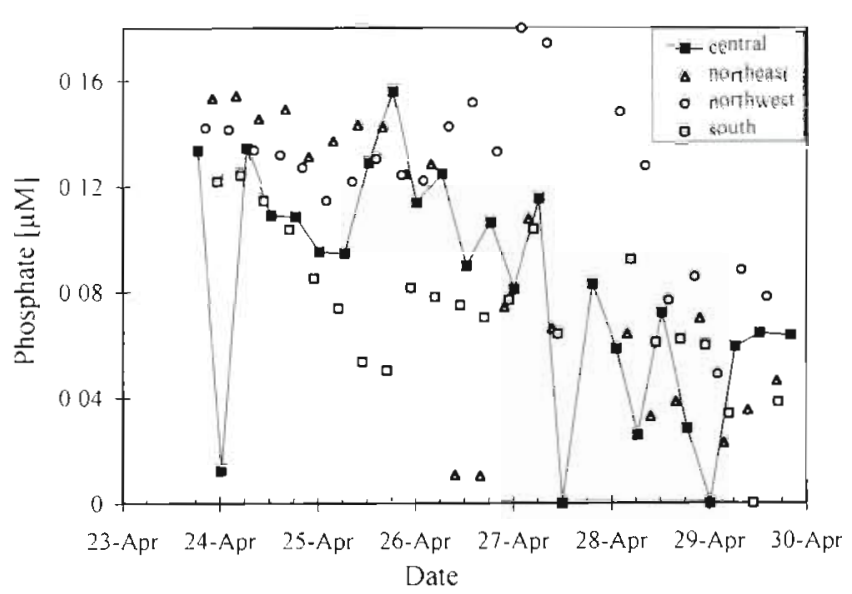

Fig. 16. Phosphate concentrations during the drift experiment in 1991 at $10 \mathrm{~m}$ depth at the 4 stations

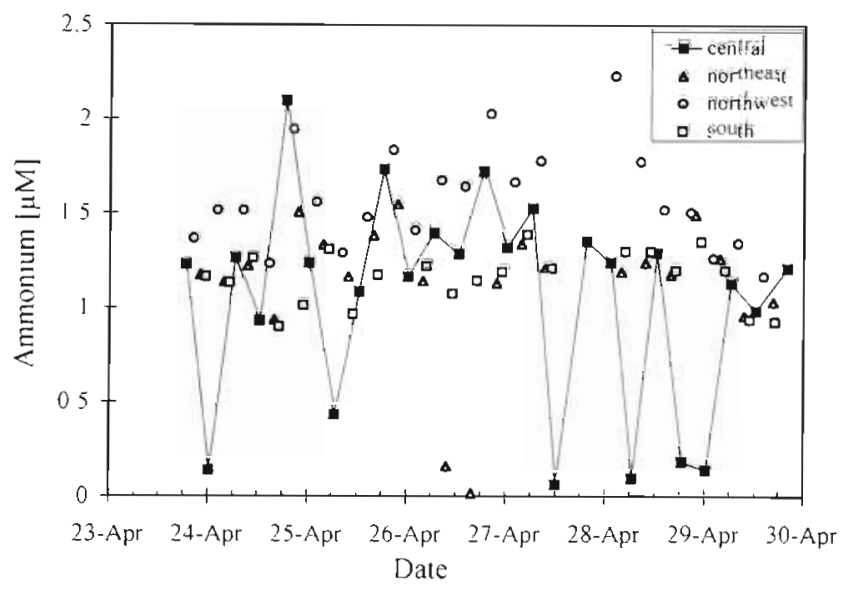

Fig. 17 Ammonium concentrations during the drift experiment in 1991 at $10 \mathrm{~m}$ depth at the 4 stations

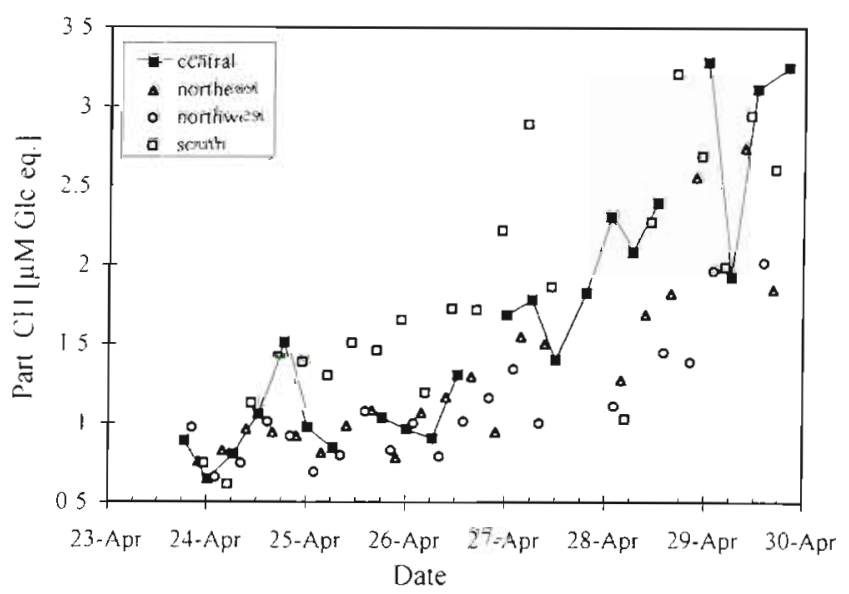

Fig. 18. Total particulate carbohydrates during the drift experiment in 1991 at $10 \mathrm{~m}$ depth at the 4 stations 


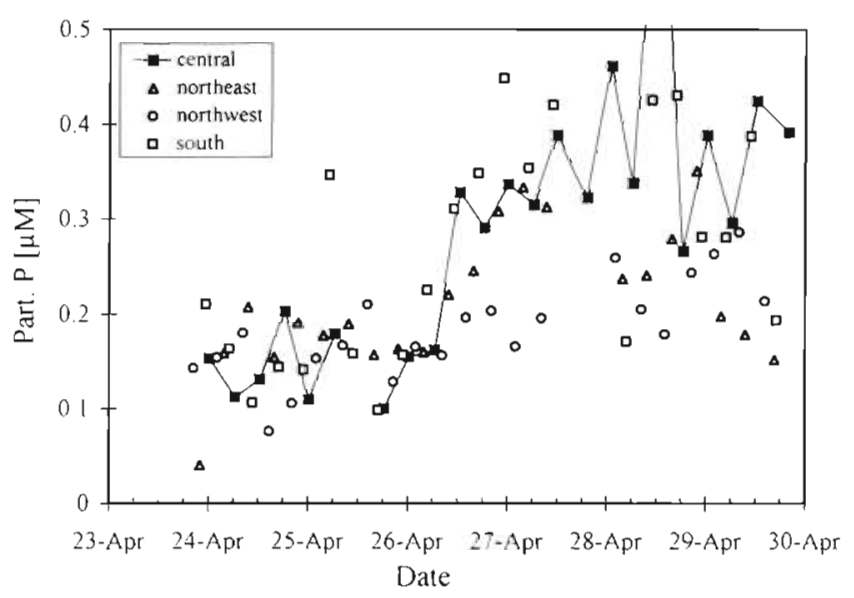

Fig. 19. Total particulate phosphorus during the drift experiment in 1991 at $10 \mathrm{~m}$ depth at the 4 stations

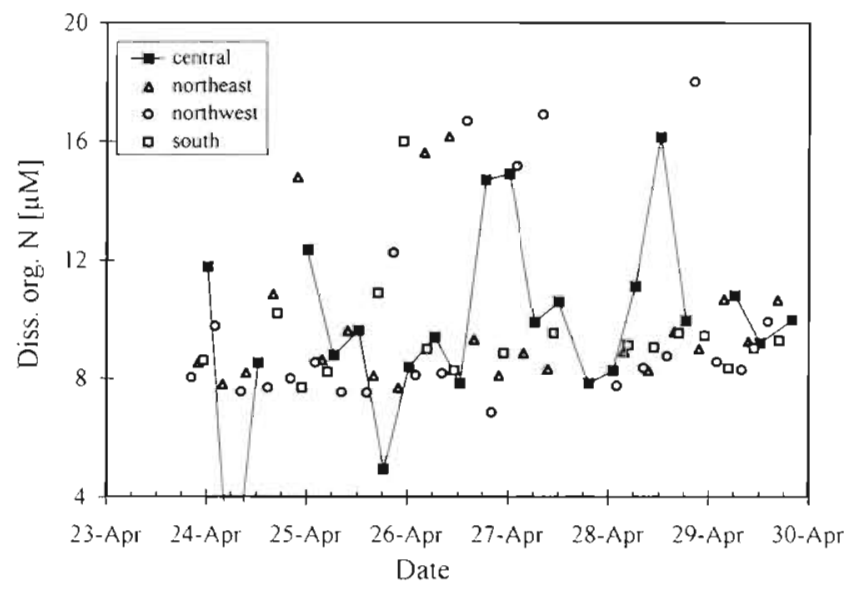

Fig. 20. Total dissolved organic nitrogen during the drift experiment in 1991 at $10 \mathrm{~m}$ depth at the 4 stations

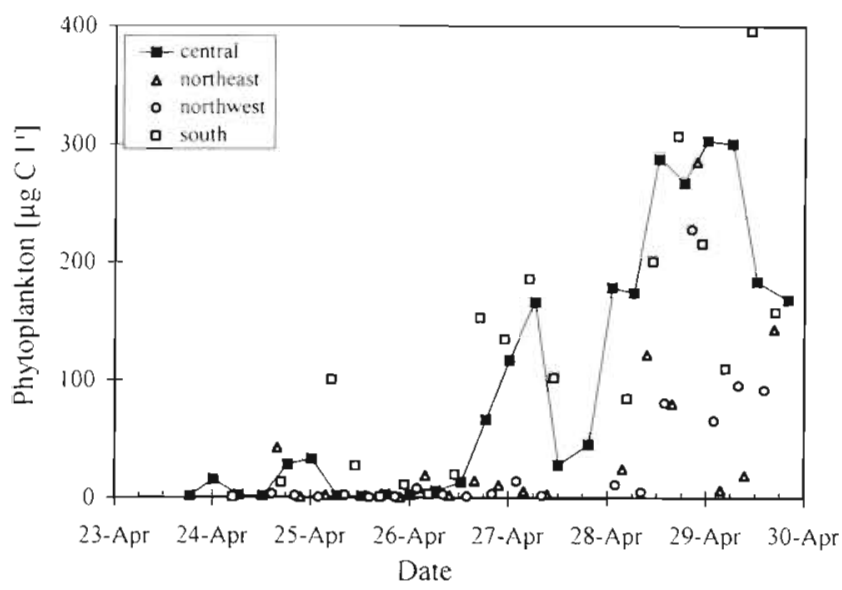

Fig. 21. Biomass of total phytoplankton (cell size $>5 \mu \mathrm{m}$ ) during the drift experiment in 1991 at the central station (depthintegrated) and the surrounding NE, NW and S stations (at $10 \mathrm{~m}$ depth)

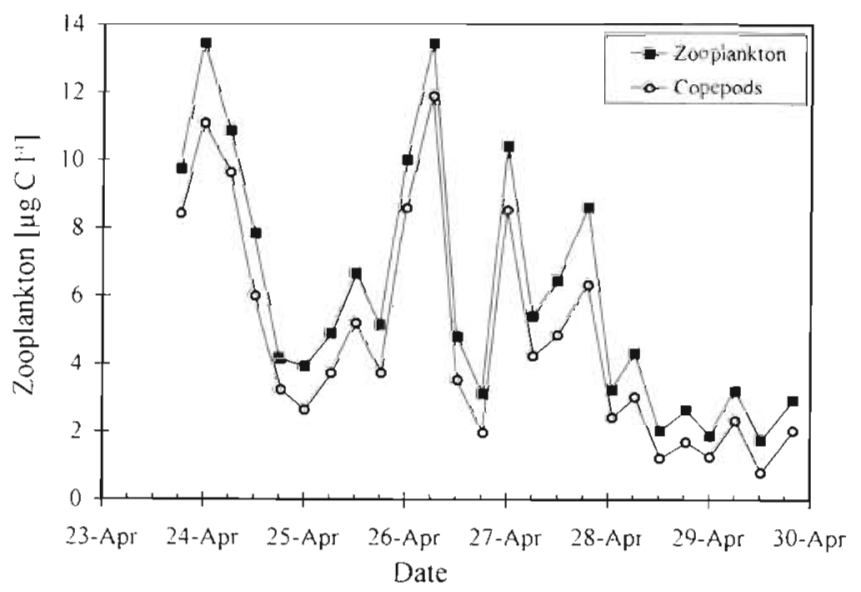

Fig. 22. Biomass of total zooplankton and copepods during the drift experiment in 1991: depth-integrated values at the central station

least $95 \%$ of the phytoplankton biomass. Diatoms, e.g. Coscinodiscus wailesii, Odontella sinensis and Thalassiosira punctigera, or dinoflagellates such as Ceratium spp. and Protoperidinium spp. were only occasionally found in net samples. In Fig. 21 the depth-integrated phytoplankton biomass (cell size $>5 \mu \mathrm{m}$ ) at the central Stn $\mathrm{Z}$ is shown.

Before April 26, only low biomass was detected. Exceptions were measured during the nights of April 24 and 25 with concentrations of 20 to $30 \mu \mathrm{g} \mathrm{C}$ $\mathrm{l}^{-1}$ phytoplankton biomass. On April 26, phytoplankton numbers strongly increased, reaching a maximum biomass of $160 \mathrm{\mu g} \mathrm{C}^{-1}$ on the morning of April 27. After a further drop to below $50 \mu \mathrm{g} \mathrm{Cl}^{-1}$, the phytoplankton biomass rose to maximum values of $300 \mu \mathrm{g}$ $\mathrm{C}^{-1}$ with the onset of April 29, then declined to $170 \mu \mathrm{g} \mathrm{Cl}^{-1}$.

\section{Zooplankton during the drift experiment}

The zooplankton biomass decreased from $13.4 \mu \mathrm{g} \mathrm{C}$ $\mathrm{l}^{-1}$ at the beginning of the experiment to $1.8 \mathrm{\mu g} \mathrm{C}^{-1}$ at the end (Fig. 22). The depth-integrated copepod biomass reached maximum values of $12 \mu \mathrm{g} \mathrm{Cl}^{-1}$ which is rather low.

Great diurnal variations were observed: the mean value from April 23 to 27 was about $6 \mu \mathrm{C} \mathrm{Cl}^{-1}$ with a standard deviation of $3 \mu \mathrm{g} \mathrm{C} \mathrm{I}^{-1}$. On April 28 the biomass decreased to a mean value of $1.8 \mathrm{\mu g} \mathrm{Cl}^{-1}$ (SD 0.75 $\mu \mathrm{g} \mathrm{C}^{-1}$ ), with minimum concentrations of below $1 \mu \mathrm{g}$ $\mathrm{C}^{-1}$ at noon on April 28 and 29. The copepods were the dominant species within the mesozooplankton community, varying between 50 and $90 \%$ of the total zooplankton biomass (species $>200 \mu \mathrm{m}$ ). 


\section{DISCUSSION}

\section{General status of the German Bight}

In April 1991 the ecological situation of the German Bight was dominated by the discharge of the river Elbe and by extensive diatom blooms spread over the whole area apart from the northwest. As a consequence, silicate, which generally has maximum concentrations exceeding $30 \mu \mathrm{M}$ in early springtime (Brockmann et al. 1990), was almost consumed at $10 \mathrm{~m}$ depth, concentrations being less than $0.3 \mu \mathrm{M}$ (Fig. 3) with the exception of the southwest, where a nutrient supply by deeper North Sea water was maintained.

Since the content of ammonium plus nitrite (Fig. 4) was higher (>2 $\mu \mathrm{M})$ in regions of higher zooplankton biomass (Fig. 11), it can be concluded that remineralisation was the dominant process here. According to Corner et al. (1965), Harris \& Malej (1986) and Checkley et al. (1992), the ammonium excretion rate by marine mesozooplankton was found to be around $1 \mu$ mol $\mathrm{N}$ (mg dry $w \mathrm{t}^{-1} \mathrm{~d}^{-1}$. Assuming a zooplankton biomass of $60 \mu \mathrm{g}$ dry wt $\mathrm{l}^{-1}$ (i.e. about $35 \mu \mathrm{g} \mathrm{Cl}^{-1}$ ), a net release of $0.06 \mu \mathrm{mol} \mathrm{NH} \mathrm{NH}^{-1} \mathrm{~d}^{-1}$ was calculated. Within $30 \mathrm{~d}$ this rate would amount to an ammonium concentration of $2 \mu \mathrm{M}$ measured in these regions if no phytoplankton uptake occurred. This could have been the case in the westernmost part of the German Bight where the phytoplankton biomass was below $1 \mu \mathrm{g} \mathrm{C}$ $l^{-1}$. Along the North Frisian coast, where more than

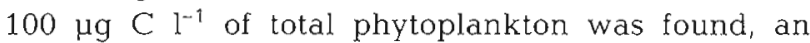

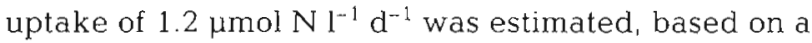
daily doubling of phytoplankton cells and on a $\mathrm{C} / \mathrm{N}$ ratio of 7 given by Hickel (1984). Although far more than the release rate of ammonium by zooplankton, the nitrogen uptake was easily compensated for by the high nitrate load of the river Elbe plume spreading along the coast. The assumption of regionally dominant grazing processes was supported by the gradients of oxygen, showing lower oxygen concentrations (Fig. 5) in the regions where oxygen-consuming processes of organic material degradation take place, releasing first ammonium and subsequently producing nitrite by nitrification.

Due to a permanent riverine supply nutrients, in particular of silicate and phosphate, the highest diatom

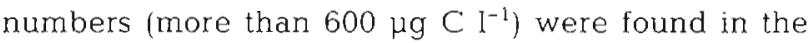
mouth of the river Elbe (Fig. 9). The biomass of total mesozooplankton exceeded $100 \mu \mathrm{g} \mathrm{Cl}^{-1}$ (Fig. 11), and the high turnover rate was indicated by a high amount of ammonium plus nitrite (more than $2.1 \mu \mathrm{M}$ ) and by lower oxygen contents (below $315 \mu \mathrm{M}$ ). In spite of high biomass, the grazing impact of zooplankton was not sufficient to decimate the phytoplankton biomass within a few days.
A different situation was found in the northeastern region near Sylt, where silicate and phosphate concentrations were close to exhaustion $(<0.3$ and $<0.05 \mu \mathrm{M}$, respectively): here the copepods represented the main part of the mesozooplankton, reaching a biomass $>45 \mu \mathrm{g} \mathrm{C} \mathrm{l}^{-1}$ (Fig. 12). Due to the combination of this grazing impact and the nutrient shortage, the diatom biomass remained well below $100 \mu \mathrm{g} \mathrm{Cl}^{-1}$.

An example for a 'top-down controlled' bloom was found in the northwest of the investigated area: in spite of high turnover rates as indicated by concentrations of ammonium plus nitrite of more than $2.1 \mu \mathrm{M}$, and sufficient concentrations of silicate and phosphate (more than 0.5 and $0.2 \mu \mathrm{M}$, respectively), the diatom biomass was below $5 \mu \mathrm{g} \mathrm{C} \mathrm{I}^{-1}$. At the same time the grazing copepods had a high biomass $\left(>35 \mu \mathrm{g} \mathrm{C}^{-1}\right)$. In this case, the diatom numbers were controlled by the grazing impact of the copepods.

In the eastern part of the German Bight along the North Frisian coast, south of the island Sylt, enrichment of particulate phosphorus and carbohydrates was found. While the particulate carbohydrate concentrations were close to the phytoplankton biomass, the amount of phosphorus exceeded the total phyto- plus zooplankton biomass: using a conversion factor $\mathrm{C} / \mathrm{P}$ of 106 (Redfield ratio), from the total particulate phosphorus concentration $(0.5 \mu \mathrm{M})$ a total carbon biomass of $640 \mu \mathrm{g} \mathrm{C} \mathrm{^{-1 }}$ was calculated for the North Frisian coastal waters, whereas total phyto- and zooplankton carbon added up to 200 to $500 \mu \mathrm{g} \mathrm{C} \mathrm{l}^{-1}$. This difference in the coastal region could have been caused by nanoand picophytoplankton, which were not analysed. Also, entrainment of detritus by river discharge and from the tidal flats of the Wadden Sea were possible sources for this phosphorus fraction (Brockmann et al. 1994).

Furthermore, the copepod biomass amounted to 10 to $20 \mu \mathrm{g} \mathrm{Cl}^{-1}$, too low to take control of the very high diatom biomass. As a consequence, this area had to be considered a temporary deposition site for sinking particulate organic materíal.

Due to the formation of a Phaeocystis globosa bloom in the southwest of the German Bight with biomasses exceeding $150 \mu \mathrm{g} \mathrm{C} \mathrm{l}^{-1}$, phosphate concentrations decreased below $0.05 \mu \mathrm{M}$. At the same time the copepod biomass remained below $15 \mu \mathrm{g} \mathrm{C} \mathrm{l}^{-1}$ and the total mesozooplankton biomass was less than $20 \mu \mathrm{g} \mathrm{Cl}^{-1}$. One possible cause for this situation could have been the fact that $P$. globosa is a colony-forming species, having only 5 to $10 \%$ of its total cell numbers as single motile cells. In fact, the major part of the Phaeocystis plankton analysed during the experiment consisted of colonies. Although isolated cells and small colonies (up to $200 \mu \mathrm{m}$ ) are easily grazed by herbivorous zooplankton, this is not the case for large colonies dominating 
the peak of the bloom (Lancelot 1990, Hansen \& Boekel 1991). Laboratory experiments showed the copepod species (adults) Acartia spp. and Temora longicornis ingesting $P$. pouchetii (syn. globosa) in the size range of 50 to $350 \mu \mathrm{m}$ (Weisse 1983). Hansen et al. (1994) previously reported that clearance and optimum prey size range of phytoplankton were both proportional to grazer size. Clearance of Phaeocystis cells by Calanus spp. was highest in the 500-100 and $100-20 \mu \mathrm{m}$ size classes for $C$. hyperboreus and in the $100-20$ and $<20 \mu \mathrm{m}$ size classes for $C$. finmarchicus. Furthermore, a high clearance of Phaeocystis colonies $>500 \mu \mathrm{m}$ accompanied by an increase of Phaeocystis cells in this size fraction was observed during grazing by Calanus spp., indicating substantial colony disruption. This was in accordance with observations made by Weisse et al. (1994) that some copepod species select for Phaeocystis while others do not.

On the other hand, Weisse et al. (1986) reported that the coincidence of a mass development of Phaeocystis pouchetii (syn. globosa) with a decline of copepod populations (Martens 1980) did not reflect a causal relationship, but was a consequence of the independent development of both populations in time

At the southwesternmost station of the grid, where Phaeocystis globosa reached maximum concentrations of more than $300 \mu \mathrm{g} \mathrm{C} \mathrm{l} \mathrm{C}^{-1}$, the ammonium plus nitrite concentrations fell below $1.3 \mu \mathrm{M}$, indicating either reduced heterotrophic decomposition activity or increased ammonium uptake by $P$. globosa to a rate as fast as that of ammonium regeneration. Similar observations were made by Eberlein et al. (1985) during a $P$. pouchetii (syn. globosa) bloom in the German Bight in 1981. These authors considered the release of acrylic acid or other antibiotic substances to inhibit grazing by heterotrophic organisms. The production of acrylic acid inhibiting both gram-negative and grampositive bacteria during blooms of $P$. globosa was reported by Sieburth (1960). Guillard \& Hellebust (1971) have also found that there are relatively few bacteria in exponentially growing cultures of $P$. globosa.

\section{Processes during the drift experiment}

The objective of the drift experiment was the identification and quantification of biological and biogeochemical processes. For a correct interpretation of the data, the variability that was superimposed on the parameters by advection processes and hydrodynamic shifts of the water body had to be identified and - as far as possible - eliminated.

During the first phase of the drift experiment from April 23 to 26 , the phytoplankton biomass was rather low (Fig. 21). The strong diurnal variations of ammonium (Fig. 17), showing maximum concentrations of 1.7 to $2 \mu \mathrm{M}$ in the evening and minimum amounts below $1 \mu \mathrm{M}$ at night (between 00:00 and 06:00 h), were due to excretion and release (e.g. by zooplankton) as well as degradation of fresh (planktonic) material at the thermocline on the one hand, and to uptake and sinking below the thermocline on the other.

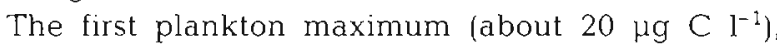
observed at midnight on April 24 at the central station, was accompanied by a sharp decrease of all nutrients (Figs. 13 to 17 ) as well as by a copepod peak of $>11 \mu \mathrm{g}$ $\mathrm{C}^{-1}$ (Fig. 22). The fact that this shift of all parameters was observed neither at other depths nor at the surrounding NE, NW and $\mathrm{S}$ stations indicates that here only a local process had taken place. As reported by König \& Schrum (1997), during the first 8 samplings the drifter moved repeatedly from east to west and back. This 'zig-zag' course was observed during the whole drift period, and it was mainly induced by tidal effects and wind impact, as shown by model results of König \& Schrum (1997).

In the evening and night of April 24, another increase of phytoplankton biomass to a concentration of $40 \mu \mathrm{g} \mathrm{C} \mathrm{l}^{-1}$ was observed. At the same time, total particulate carbohydrates and phosphorus (Figs. 18 \& 19) were minimal, as was the copepod biomass (below $3 \mu \mathrm{g} \mathrm{C} \mathrm{^{-1 }}$, whereas the silicate concentration increased $(+0.15 \mu \mathrm{M})$. Since the salinity rose slightly (+0.02 PSU), a shift of the drifter out of the original water mass was assumed to have occurred. Also, vertical mixing processes had to be taken into account, due to a strong vertical shear within the water column during the first days (Brockmann et al. 1997, Schrum et al.1997)

Overnight on April 26, nitrate and silicate concentrations rose $(+1$ and $+1.5 \mu \mathrm{M}$, respectively) as did the copepod biomass $\left(+10 \mu \mathrm{g} \mathrm{Cl}^{-1}\right)$. At the same time, the salinity increased (+0.03 PSU). By this time the drifter had moved southwest (sampling numbers 9, 10, 11; see König \& Schrum 1997), and the concentrations of nitrate, nitrite and phosphate at the central station approached the concentrations found at the northeast station (Figs. 13, $15 \& 16$ ). This and the increasing salinity led to the conclusion that the water masses at the central Stn Z had been influenced by the nutrientrich upwelling water west of Helgoland (see above).

With increasing wind velocities on April 26 the drifter started to move southwards (sampling numbers 12 to 16 ; see König \& Schrum 1997), resulting in a clear drop in the nitrate concentrations $(-1.5 \mu \mathrm{M})$ and an increase in the concentrations of silicate $(+0.4 \mu \mathrm{M})$, particulate carbohydrates $(+0.8 \mu \mathrm{M})$, particulate phosphorus $(+0.2 \mu \mathrm{M})$ and phytoplankton biomass $(+150 \mu \mathrm{g}$ $\mathrm{C}^{-1}$ ). This and the results of the preceding survey sup- 
ported the assumption that the drifter had already moved through patches of a beginning bloom of Phaeocystis globosa in the southern part of the drift area.

On the evening of April 27, the drifter had reached the southern part of the drift area (sampling 17; see König \& Schrum 1997). At this point the constellation of parameters changed and the second phase of the drift experiment started. In the course of this drift phase, nitrate and nitrite concentrations steadily declined, accompanied by a strong increase in total particulate carbohydrates and phytoplankton biomass. At the same time, the salinity slightly decreased.

In order to get an idea of the physical and biogeochemical processes caused by real phase-transfer processes during this period and to identify and sort out distorting advection processes, as indicated mainly by shifts in the salinity values, the following calculations were made: Assuming that nitrate levels mainly followed changes in salinity below the euphotic zone, a linear regression of nitrate versus salinity was calculated for April 23 to 29 (Fig. 23), taking into account all depths $>15 \mathrm{~m}$ at Stns $\mathrm{Z}, \mathrm{NE}, \mathrm{NW}$ and $\mathrm{S}$. This regression had very high significance and explained more than $50 \%$ of the variability $\left(p<0.001, r^{2}=0.530, n=173\right)$.

In the next step the regression parameters were used to calculate expected nitrate concentrations by putting the respective salinity values into the equation. The differences between the measured and the calculated nitrate concentrations are given in Fig. 24. The 2 phases of the drift experiment and the transition state when the drifter moved south are indicated.

During the first phase, the mean value of the differences between measured and calculated nitrate concentrations was near zero. The peaks deviating from the zero line indicated patches of water masses with a different biological state into which the drifter had temporarily moved.

In the transition state, nitrate differences dropped to $-1 \mu \mathrm{M}$ and remained below zero until the second phase of the drift started. This period represents a state with higher biological activity, where constant fixation of dissolved nutrients resulted in higher amounts of particulate compounds.

During the second phase of the drift experiment, the differences between measured and calculated nitrate concentrations increased from 0 to $-2 \mu \mathrm{M}$. Within this period, the phytoplankton biomass increased exponentially (Fig. 21) as did the particulate compounds such as carbohydrates and phosphorus. Assuming a Redfield ratio for $\mathrm{C} / \mathrm{N}$ of 7 , the overall nitrate decrease of almost $2 \mu \mathrm{M}$ corresponded to a total biomass formation of $160 \mu \mathrm{g} \mathrm{Cl}^{-1}$. This was in fact on the same order as that of the increase in phytoplankton biomass during the second phase, indicating again that during this

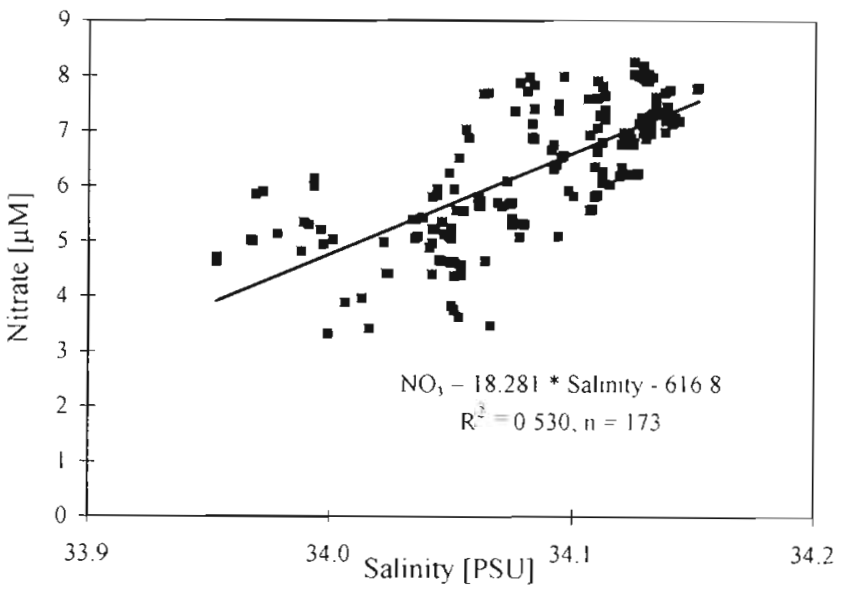

Fig. 23. Linear regression of nitrate concentrations versus salinity during the drift experiment from 22 to 29 April 1991 at the central station and at the surrounding NE, NW and $S$ stations (all depths)

drift phase concentration changes were dominated by biological processes. Furthermore, this supports the assumption that the observed bloom had been mainly dominated by phytoplankton cells of a size $>5 \mu \mathrm{m}$, because nano- and picophytoplankton was not included in the analysis.

The zooplankton population declined after a final maximum on the evening of April 27. The copepod biomass, for example, decreased from $6.5 \mathrm{\mu g} \mathrm{C}^{-1}$ (noon of April 27) to below $2 \mu \mathrm{g} \mathrm{Cl}^{-1}$ at 18:00 h on April 29, when the drift experiment was terminated. Whether this decrease was due to inhibiting factors produced by the developing Phaeocystis bloom (Eberlein et al.

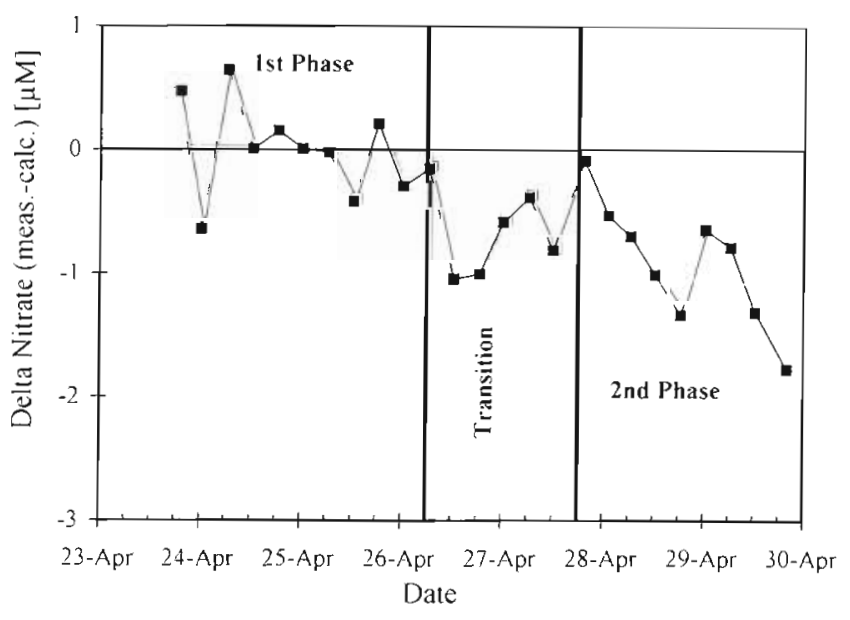

Fig. 24. Differences between measured nitrate concentrations and nitrate calculated from the linear regression parameters in at the central station at $10 \mathrm{~m}$ depth during the drift experiment in 1991 
1985) or was just a consequence of the independent development of both populations (Weisse 1983), as discussed above, cannot be deduced.

Whenever phosphate concentrations were close to exhaustion $(<0.03 \mu \mathrm{M})$, a temporary stagnation of the exponentially growing bloom was observed. Phosphate showed a negative linear correlation of very high significance $(p<0.001)$ with the phytoplankton biomass. Furthermore, the distinct diurnal maxima and minima of phosphate and ammonium were very well correlated. These major variations in concentrations were not found in the surface layer, nor at $20 \mathrm{~m}$ depth, an indication that phase-transfer processes mainly took place at $10 \mathrm{~m}$. From the minima of phosphate and ammonium, maximal uptake rates of these nutrients by phytoplankton could be calculated: $15 \mathrm{nmol}^{-1} \mathrm{~h}^{-1}$ for phosphate and $25 \mathrm{nmol} \mathrm{l}^{-1} \mathrm{~h}^{-1}$ for ammonium. This was in good agreement with results from Veldhuis et al. (1987) who reported an orthophosphate uptake of 0.01 to $0.02 \times 10^{-6} \mathrm{nmol} P \mathrm{~min}^{-1}$ cell $^{-1}$ by Phaeocystis pouchetii for a phosphate concentration of less than $0.2 \mu \mathrm{M}$. For a Phaeocystis cell number of 20 million $\mathrm{l}^{-1}$ found during the exponential growth phase of the drift,

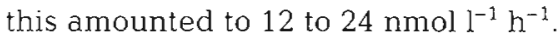

No significant linear correlation between dissolved inorganic phosphate and total particulate phosphorus concentrations was found, but phosphate minima were accompanied by maxima of dissolved organic phosphorus (not shown) and vice versa, indicating utilization as well as production of phosphorus by microorganisms. This was in accordance with observations made by Tamminen (1989) who considered pico- and nanoplanktonic bacteria, algae and flagellates as playing an important role in the nutrient cycle.

Overall, the concentrations of nitrate, phosphate, nitrite and ammonium decreased. This was due to uptake and fixation by particulate material. At the same time the remineralization processes slowed down, due to the decreasing zooplankton numbers. On the evening of April 29, when the drift experiment was terminated, the phytoplankton biomass had declined from more than $300 \mu \mathrm{g} \mathrm{C} \mathrm{l^{-1 }}$ to below $200 \mu \mathrm{g} \mathrm{C} \mathrm{l^{-1 }}$ within $12 \mathrm{~h}$, indicating that the exponential growth phase of the plankton was terminated by phosphate limitation. This assumption is supported by the increase in particulate carbohydrates and particulate phosphorus at the end of the second phase, caused by an ongoing primary production without sufficient nutrient supply. Furthermore, the mean increase in dissolved organic nitrogen of $2 \mu \mathrm{M}$ (Fig. 20) indicated the transfer of inorganic nutrient elements into dissolved organic matter via biomass transformation. This net process is seasonal (Butler et al. 1979).

Summing up the results discussed above, the following conclusions can be drawn: The strategy of locating a drifter in an area where surrounding stations were sampled, and of integrating this drift area into stationgrid-based surveys of the German Bight, was successful. Because the drifter course was strongly dependent on the meteorological and hydrodynamic conditions, it was not always possible to track the same water masses for a longer period. But during the periods when the drifter stayed within the same water body, biogeochemical processes could be traced, and basic phase-transfer processes were identified. These processes mainly occurred at a depth of $10 \mathrm{~m}$ and in part showed strong diurnal variations, from which maximal turnover rates could be calculated. For future experiments it would be a good idea to track the successive blooms of diatom species and Prymnesiophyceae such as Phaeocystis spp. in combination with extensive zooplankton analysis and rate measurements. Analysis of nano- and picophytoplankton as well as of small zooplankton has to be included. Furthermore, the bacterial activity in the water column should be investigated by microbiologists in order to relate changes in nutrient composition to microbial processes.

Acknowledgements. This study was a contribution to the project PRISMA, funded primarily by the Bundesminister für Forschung und Technologie under contract no. 03F0558A1. Sincere thanks for their excellent work to the technicians Monika Schütt and Ilse Büns.

\section{LITERATURE CITED}

BAH (1992) Jahresbericht der Biologischen Anstalt Helgoland 1991. BAH, Hamburg

Brockmann UH, Eberlein K (1986) River input of nutrients into the German Bight. In: Skreslet S (ed) The role of freshwater outflow in coastal marine ecosystems. SpringerVerlag, Berlin, p 231-240

Brockmann UH, Laane RW, Postma H (1990) Cycling of nutrient elements in the North Sea. Neth J Sea Res 26:239-264

Brockmann UH, Pohlmann T, Becker G, König P, Aletsee L. Rick HJ, Krause M, Martens P, Knickmeyer R, Heyer K (1994) Ecological situation in the North Sea during spring and winter 1986/87. In: Sündermann J (ed) Circulation and contaminant fluxes in the North Sea. SpringerVerlag, Berlin, p 56-89

Brockmann UH, Raabe T, Nagel K, Haarich M (1997) Measurement strategy of PRISMA: design and realisation. Mar Ecol Prog Ser 156:245-254

BSH (1993) Transport, Umsatz und Variabilität von Schadund Nährstoffen in der Deutschen Bucht 1990-1992 (TUVAS) Abschlußbericht Teil 1+2, Bundesamt für Seeschiffahrt und Hydrographie, Hamburg

Budéus G (1989) Frontal variability in the German Bight. Scient Mar 53:175-185

Butler EI, Knox S, Liddicoat MJ (1979) The relationship between inorganic and organic nutrients in sea water. J Mar Biol Assoc UK 59:239-250

Checkley DM, Dagg MJ, Uye Sl (1992) Feeding, excretion and egg production by individuals and populations of the marine, planktonic copepods, Acartia spp. and Centropages furcatus. J Plankton Res 14:71-96 
Comita GW, Marshall SM, Orr AP (1966) On the biology of Calanus finmarchicus XIII. Seasonal change in weight, calorific value and organic matter. J Mar Biol Assoc UK $46: 1-1.7$

Corner EDS, Cowey CB, Marshall SM (1965) On the nutrition and metabolism of zooplankton: III. Nitrogen excretion by Calanus. J Mar Biol Assoc UK 45:429-442

Cushing DH, Humphrey GF, Banse K, Laevastu T (1958) Report of the Committee on Terms and Equivalents. Rapp P-v Réun Cons Int Explor Mer 144:15-16

Daro $\mathrm{MH}$, Gijsegem B van (1982) Ecological factors affecting five dominant copepods in the southern bight of the North Sea, as regards their seasonal variations of weight. ICES, Copenhagen

Dippner JW (1993) A frontal-resolving model for the German Bight. Cont Shelf Res 13:49-66

Eberlein K, Lea] MT, Hammer KD, Hickel W (1985) Dissolved organic substances during a Phaeocystis pouchetil bloom in the German Bight (North Sea) Mar Biol 89:311-316

Grasshoff K, Ehrhardt M, Kremling K (1983) Methods of seawater analysis. Verlag Chemie, Weinheim

Guillard RRL, Hellebust JA (1.971) Growth and the production of extracellular substances by two strains of Phaeocystis pouchetii. J Phycol 7:330-338

Hagmeier E (1.961) Plankton-Äquivalente. Kieler Meeresforsch $17: 32-47$

Hansen B, Verity P, Falkenhaug $T$, Tande KS, Norrbin F (1994) On the trophic fate of Phaeocystis pouchetii (Harriot). V. Trophic relationships between Phaeocystis and zooplankton: an assessment of methods and size dependence. J Plankton Res 16:487-511

Hansen FC, Boekel WHM van (1991) Grazing pressure of the calanoid copepod Temora longicornis on a Phaeocystis dominated spring bloom in a Dutch coastal inlet. Mar Ecol Prog Ser 78:123-129

Harms J, Meyer-Harms B, Dawirs RR, Anger K (1994) Growth and physiology of Carcinus maenas (Decapoda, Portunidae) larvae in the field and in laboratory experiments. Mar Ecol Prog Ser 108:107-118

Harris RP, Malej A (1986) Diel patterns of ammonium excretion and grazing rhythms in Calanus helgolandicus in surface stratified waters. Mar Ecol Prog Ser 31:75-85

Hickel W (1984) Seston in the Wadden Sea of Sylt (German Bight, North Sea). Publ Ser Neth Inst Sea Res, no. 10. p 113-132

Hillebrandt $M$ (1972) Untersuchungen über die qualitative und quantitative Zusammensetzung des Zooplanktons in der Kieler Bucht während der Jahre 1966-68. PhD thesis, Universität Kiel

Kirkegaard E, Lassen H (1980) Biomass estimates of $p_{\text {seudo- }}$ calanus CVI in the North Sea 1958-1975. ICES CM1980/L:30, Biological Oceanographic Committee

König P, Schrum C (1997) Hydrographic observatıons and model results from a PRISMA drift experiment. Mar Ecol Prog Ser 156:255-261

Krause G, Budeus G. Gerdes G, Schaumann K. Hesse K (1986) Frontal systems in the German Bight and their physical and biological effects. In: Nihoul JCJ (ed) Marine interfaces ecohydrodynamics. Elsevier Oceanography

This article was submitted to the editor
Series 42. Elsevier, Amsterdam, p 119-140

Lancelot $C$ (1990) Phaeocystis blooms in the contınental coastal area of the Channel and the North Sea. In: Eutrophication and algal blooms in North Sea coastal zones, the Baltic and adjacent areas: prediction and assessment of preventive actions Wat Pollut Res Rep 12: $27-54$

Martens P (1980) Beiträge zum Mesozooplankton des Nordylter Wattenmeeres. Helgoländer Wiss Meeresunters 34: $41-53$

Mills DK, Tett PB (1991) Phytoplankton and fronts in the southern North Sea. ICES, Copenhagen

Munk P (1993) Differential growth of larval sprat Sprattus sprattus across a tidal front in the eastern North Sea. Mar Ecol Prog Ser 99:17-29

Pohlmann T, Puls W (1994) Currents and transport in water In: Sündermann J (ed) Circulation and contaminant fluxes in the North Sea. Springer-Verlag. Berlin, p 345-402

Schrum C, König P, Michaelsen K, Niemeier U, Pohlmann T (1997) Meteorological and oceanographic situation in the German Bight from 23 to 29 April 1991. Mar Ecol Prog Ser 156:263-273

Sieburth JMcN (1960) Acrylic acid, an antibiotic principle in Phaeocystis blooms in Antarctic waters. Science 132: 676-677

Strickland JDH, Parsons TR (1972) A practical handbook of seawater analysis. Bull Fish Res Board Can 167

Sündermann J (ed) (1994) Circulation and contaminant fluxes in the North Sea. Springer-Verlag, Berlin

Sündermann J, Lenz W (eds) (1983) North Sea dynamics. Springer-Verlag, Berlin

Tamminen T (1989) Dissolved organic phosphorus regeneration by bacterioplankton: 5'-nucleotidase activity and subsequent phosphate uptake in a mesocosm enrichment experiment. Mar Ecol Prog Ser 58:89-100

Utermöhl H (1931) Über das umgekehrte Mikroskop. Arch Hydrobiol Plankt 22:643-645

Utermöh] H (1958) Zur Vervollkommnung der quantitativen Planktonmethodik. Mitt Int Verh Theor Angew Limnol 9: $1-38$

Veldhuis MJW, Colijn F, Admiraal W (1987) Phosphate utilization in Phaeocystis pouchetii (Haptophyceae) In: Veldhuis MJW (ed) The ecophysiology of the colonial alga Phaeocystis pouchetii. PhD thesis, University of Groningen, p $62-77$

Weisse $T$ (1983) Feeding of calanoid copepods in relation to Phaeocystis pouchetii blooms in the German Wadden area off Sylt. Mar Biol 74:87-94

Weisse T, Grimm N, Hickel W, Martens P (1986) Dynamıcs of Phaeocystus pouchetii blooms in the Wadden Sea of Sylt (German Bight, North Sea). Estuar Coast Shelf Sci 23: $171-182$

Weisse T, Tande K, Verity P, Hansen F, Gieskes W (1994) The trophic significance of Phaeocystis blooms. J Mar Syst 5 : $67-79$

Williams R, Lindley JA (1980) Plankton of the Fladen Ground during FLEX'76. III. Vertical distribution, population dynamics and production of Calanus finmarchicus. Mar Biol 60:47-56

Manuscript received: January 2, 1997

Revised version accepted: June 2, 1997 